\title{
Impact of pleural integrity during mammary artery harvesting on short term outcome
}

\author{
M Pano ${ }^{1 *}$, S Zaccaria', A Scotto di Quacquaro', G Floris ${ }^{1}$, D Rocco ${ }^{1}$, P Fellini', G Scrascia ${ }^{1}$, P Pelini ${ }^{1}$, M Cucurachi ${ }^{2}$ \\ From 23rd World Congress of the World Society of Cardio-Thoracic Surgeons \\ Split, Croatia. 12-15 September 2013
}

\section{Background}

The aim of this retrospective study was to evaluate if the impact of pleural integrity during left internal mammary artery (LIMA) harvesting might influence short term outcome.

\section{Methods}

From May 2012 to May 2013, 136 patients undergoing isolated CABG operation (with or without pump) were enrolled in the study. The mammary artery was always harvested in a skeletonized fashion. These patients were split in two groups: Group A (96 pts) with open pleura and Group B (40 pts) with intact pleura. The two groups were comparable regarding pre- and operative data.

\section{Results}

There were no differences in mean values between Group A and Group B for: Age, BMI, LVEF, CPB time, Cross-clamp time, Number of anastomoses / patients. Group A and Group B were significantly different in terms of ventilation time $(13,47+/-18,2 \mathrm{~h}$ vs $8,4+/-6,3 \mathrm{~h}$, $\mathrm{p}<0,001)$, bleeding within $12 \mathrm{~h}(540,31+/-283,5 \mathrm{ml}$ vs $392,25+/-257,8 \mathrm{ml}, \mathrm{p}<0,001)$, blood transfusion units $(1,38+/-1,6$ vs $0,6+/-1,4, \mathrm{p}<0,001)$, and length of hospital stay $(14,7+/-14,3$ day vs $11,2+/-7, \mathrm{p}<0,001)$.

\section{Conclusions}

Our data showed that preservation of pleura integrity, when possible, during LIMA harvesting has a strong impact on post-operative course. Pleural integrity can reduce postoperative bleeding with a minor need of blood transfusion. Very likely these finding along with a

\footnotetext{
* Correspondence: marcopano@alice.it

${ }^{1}$ Department of Cardiac Surgery, "Vito-Fazzi" Hospital, Lecce, Italy
}

Full list of author information is available at the end of the article less time of ventilation might reduce the length of hospital stay.

\section{Authors' details}

'Department of Cardiac Surgery, "Vito-Fazzi" Hospital, Lecce, Italy.

2Department of Cardiac Anesthesia, "Vito-Fazzi" Hospital, Lecce, Italy.

Published: 11 September 2013

doi:10.1186/1749-8090-8-S1-0120

Cite this article as: Pano et al:: Impact of pleural integrity during mammary artery harvesting on short term outcome. Journal of Cardiothoracic Surgery 2013 8(Suppl 1):0120.
Submit your next manuscript to BioMed Central and take full advantage of:

- Convenient online submission

- Thorough peer review

- No space constraints or color figure charges

- Immediate publication on acceptance

- Inclusion in PubMed, CAS, Scopus and Google Scholar

- Research which is freely available for redistribution

Submit your manuscript at www.biomedcentral.com/submit

\section{() Biomed Central}

